\title{
PENGARUH KONFLIK PERAN GANDA, KECERDASAN EMOSIONAL DAN KOMITMEN ORGANISASI TERHADAP KINERJA PERAWAT DI RSUD SULTAN SULAIMAN SEI RAMPAH
}

\author{
Juniarta Br Sinaga ${ }^{1)}$, \& Armin Rahmansyah Nasution ${ }^{2)^{*}}$ \\ 1) Fakultas Ekonomi, Universitas Negeri Medan \\ 2) Fakultas Ekonomi, Universitas Negeri Medan \\ E-mail : armin.nasution@yahoo.com
}

\begin{abstract}
Abstrak
Penelitian ini bertujuan untuk mengetahui pengaruh Konflik Peran Ganda, Kecerdasan Emosional dan Komitmen Organisasi Terhadap Kinerja Perawat di RSUD Sultan Sulaiman Sei Rampah. Sampel dalam penelitian ini adalah seluruh perawat wanita yang sudah menikah, memiliki anak serta berstatus tenaga kerja honorer sebanyak 78 orang.Pengujian yang digunakan adalah uji kualitas data dan uji asumsi klasik. Pengujian hipotesis menggunakan analisis regresi linier berganda, uji $\mathrm{F}$ dan uji t. Konflik Peran Ganda, Kecerdasan Emosional dan Komitmen Organisasi bersama-sama berpengaruh signifikan terhadap Kinerja Perawat di RSUD Sultan Sulaiman Sei Rampah.
\end{abstract}

Kata Kunci : Konflik Peran Ganda, Kecerdasan Emosional, Komitmen Organisasi, Kinerja

\begin{abstract}
This study aims to determine whether there is influance of between dual role conflict (work-family conflict), emotional intelligence and organizational commitment performance againts nurses in Hospital Sultan Sulaiman Sei Rampah.The sample in this study aims all nurses women who are married, have children and employment status of honorary many as 78 people. Test are used to test the quality of the data and classical asumption. The hypothesis test uses multiple linear regression analysis $F$ test and $t$ test. That dual role conflict (work-family conflict), emotional intelligance and organizational commitment together significantly influance nurses performance in the Hospital Sultan Sulaiman Sei Rampah.
\end{abstract}

Keywords : Dual Role Conflict, Emotional Intelligance, Organizational Commitment, Performance

\section{PENDAHULUAN}

Sumber daya manusia yang berkualitas merupakan hal yang sangat penting bagi perusahaan untuk menghasilkan produktifitas kinerja yang baik dan mencapai tujuan organisasi secara efektif sehingga mampu menempatkan perusahaan pada posisi persaingan pasar yang sangat kuat dibanding dengan perusahaan lain. Tanpa ada sumber daya manusia yang terampil dan kompeten maka perusahaan tidak akan berproduktifitas dengan baik. Kinerja karyawan yang tinggi sudah menjadi salah satu sasaran semua perusahaan, karena peningkatan tersebut akan mendorong kinerja karyawan secara keseluruhan yang 
direfleksikan dalam kenaikan produktivitas.

Pada era globalisasi seperti saat ini, emansipasi wanita bukanlah hal asing yang sering didengar. R.A Kartini merupakan salah satu pahlawan nasional Indonesia dan merupakan pencetus emansipasi wanita. Ia diposisikan sebagai pejuang dan pahlawan emansipasi wanita Indonesia karena pemikirannya yang maju mengenai wanita Indonesia yang dikemukakannya dalam surat-surat korespondensinya dengan Rosa Abendanon yang kemudian hari diterbitkan dalam buku berjudul Door Duisternis Tot Licht (Habis Gelap Terbitlah Terang). Kartini menjadi inspirasi karena keberaniannya mendobrak tata-tata nilai yang berlaku saat itu. Emansipasi wanita telah memaksa kaum wanita untuk bisa terampil lebih baik dan membuatnya sama seperti kaum lakilaki dalam segala hal.

Kesejajaran kedudukan antara wanita dan laki-laki bukan merupakan kendala bagi wanita untuk melakukan pekerjaan yang bisa dilakukan oleh laki-laki seperti halnya mencari nafkah atau bekerja dan bertanggungjawab untuk memenuhi kebutuhan hidup keluarganya. Karena yang kita ketahui pada saat ini, banyak sekali kebutuhan yang harus dipenuhi dalam kehidupan ini, mulai dari kebutuhan primer, sekunder dan tersier. Maka dari itu, banyaknya kebutuhan yang harus dipenuhi maka seorang wanita mulai bekerja. Wanita juga turut menyumbang dalam pembangunan perekonomian, hal tersebut dapat dilihat pada data ketenagakerjaan.
Tabel 1. Data Lowongan Kerja Terdaftar dan Penempatan/Pemenuhan Tenaga Kerja Menurut Jenis Kelamin 2013-2015 di Indonesia

\begin{tabular}{|c|c|c|c|c|c|c|}
\hline \multirow[t]{2}{*}{$\begin{array}{l}\text { Tah } \\
\text { un }\end{array}$} & \multicolumn{3}{|c|}{$\begin{array}{c}\text { Lowongan Kerja } \\
\text { Terdaftar }\end{array}$} & \multicolumn{3}{|c|}{$\begin{array}{c}\text { Penempatan/pemenuha } \\
\mathrm{n} \\
\text { Tenaga Kerja }\end{array}$} \\
\hline & $\mathrm{L}$ & $\mathrm{P}$ & Total & $\mathrm{L}$ & $\mathrm{P}$ & Total \\
\hline $\begin{array}{l}201 \\
3\end{array}$ & $\begin{array}{l}290 . \\
864\end{array}$ & $\begin{array}{l}321 . \\
835\end{array}$ & $\begin{array}{l}612 . \\
699\end{array}$ & $\begin{array}{l}197 . \\
138\end{array}$ & $\begin{array}{l}211 . \\
914\end{array}$ & $\begin{array}{l}409 . \\
052\end{array}$ \\
\hline $\begin{array}{l}201 \\
4\end{array}$ & $\begin{array}{l}473 . \\
889\end{array}$ & $\begin{array}{l}342 . \\
661\end{array}$ & $\begin{array}{l}816 . \\
505\end{array}$ & $\begin{array}{l}336 . \\
573\end{array}$ & $\begin{array}{l}288 . \\
614\end{array}$ & $\begin{array}{l}625 \\
187\end{array}$ \\
\hline $\begin{array}{l}200 \\
15\end{array}$ & $\begin{array}{l}421 . \\
987\end{array}$ & $\begin{array}{l}411 . \\
568\end{array}$ & $\begin{array}{l}833 . \\
555\end{array}$ & $\begin{array}{l}398 . \\
189\end{array}$ & $\begin{array}{l}343 . \\
988\end{array}$ & $\begin{array}{l}742 . \\
177\end{array}$ \\
\hline
\end{tabular}

Menurut Badan Pusat Statistik (BPS) jumlah pekerja wanita di Indonesia mengalami peningkatan. Pada tahun 2013 jumlah wanita yang mencari lowongan pekerjaan tercatat 321.835 orang, naik sebesar 20.286 orang ke tahun 2013. Dan meningkat tiga kali lipat menjadi 411.568. Sedangkan penempatan tenaga kerja atau pemenuhan tenaga kerja wanita tahun 2013-2015 juga mengalami kenaikan sebanyak 132.074 orang. Peningkatan jumlah lowongan kerja terdaftar dan penempatan atau pemenuhan tenaga kerja disertai dengan peningkatan jumlah penduduk Indonesia yang tercatat di BPS sebesar 13.326.307 orang tahun 2013 menjadi 13.937 .797 orang pada tahun 2015.

Tabel 2. Lowongan Kerja Terdaftar dan Penempatan/Pemenuhan Tenaga Kerja Menurut Jenis Kelamin 20132015 di Sumatera Utara

\begin{tabular}{|l|l|l|l|l|l|l|}
\hline \multirow{2}{*}{ Tahun } & \multicolumn{3}{|l|}{$\begin{array}{l}\text { Lowongan Kerja } \\
\text { Terdaftar }\end{array}$} & \multicolumn{3}{l|}{$\begin{array}{l}\text { Penempatan/pemenuhan } \\
\text { Tenaga Kerja }\end{array}$} \\
\cline { 2 - 7 } & L & P & Total & L & P & Total \\
\hline 2013 & 532 & 1.221 & 1.753 & 138 & 1.056 & 1.194 \\
\hline 2014 & 753 & 1.300 & 2.053 & 235 & 1.438 & 1.673 \\
& & & & & & \\
\hline 2015 & 671 & 1.562 & 2.233 & 278 & 1.714 & 1.992 \\
\hline
\end{tabular}

Sumber dari : Badan Pusat Statistik (BPS)

Hal serupa dialami di Provinsi

Sumatera Utara dari tahun 2013-2015 mengalami peningkatan lowongan kerja terdaftar dan penempatan atau 
pemenuhan tenaga kerja. Secara spesifik peningkatan jumlah tenaga kerja medis di Sumatera Utara, terkhusus di Kabupaten Serdang Bedagai juga mengalami peningkatan.

Tabel 3. Jumlah Tenaga Medis di Kabupaten Serdang Bedagai Tahun 2013 2015

\begin{tabular}{|l|l|l|l|l|}
\hline \multirow{2}{*}{ No } & \multirow{2}{*}{ Tahun } & \multicolumn{3}{|l|}{ Tenaga Medis } \\
\cline { 3 - 5 } & & $\begin{array}{l}\text { Dokter } \\
\text { Umum }\end{array}$ & Perawat & Bidan \\
\hline 1 & 2013 & 83 & 406 & 279 \\
\hline 2 & 2014 & 99 & 434 & 570 \\
\hline 3 & 2015 & 103 & 406 & 279 \\
\hline \multicolumn{5}{|l}{ Sumber dari : Dinas Kesehatan Provinsi Sumatera Utara }
\end{tabular}

Menurut Jacinta (2002)

pilihan wanita untuk bekerja dilandasi oleh motif kerja sebagai berikut : (a) kebutuhan financial, (b) kebutuhan sosial-relasional, (c) kebutuhan aktualisasi diri, dan (d) merasa lebih rileks dan nyaman ketika bekerja. Wanita juga ikut berpartisipasi dan bersaing dalam dunia kerja meskipun seorang wanita memiliki tanggung jawab yang lain dalam mengurus rumah tangga dan anak-anak mereka. Wanita mulai dipercaya untuk menduduki posisi yang cukup tinggi di sebuah perusahaan atau organisasi, hal ini akan menjadi masalah ketika ia sudah menikah dan memiliki jabatan serta gaji yang lebih tinggi dari suami.

Wanita juga akan terbentur dengan kodrat yang dibawanya, dimana tugas ataupun peran seorang wanita adalah bertugas dirumah untuk melayani suami dan mendidik anakanak mereka, bukan bekerja dan menanggung beban serta tanggungjawab yang besar di pekerjaan mereka untuk menafkahi keluarganya. Wanita yang sudah bekerja namun yang belum memiliki anak bukan berarti mereka tidak memiliki konflik. Dalam kehidupan berumah tangga konflik tidak hanya disebabkan dari sikap dan tingkahlaku dari anak-anak. Namun konflik bisa muncul dari keadaan suami ataupun pihak keluarga mereka. Sehingga menyebabkan banyak pemikiran yang negatif oleh istri yang dapat mengganggu pekerjaan mereka. Dengan pekerjaan mereka sebagai perawat di suatu instansi pemerintahan yaitu rumah sakit tidak baik bagi mereka bekerja dengan keadaan pikiran yang sedang kacau, itu akan mengakibatkan kefatalan apabila mereka tidak berkonsentrasi dengan pekerjaannya. Ketidakselarasan pemenuhan kedua peran tersebut dapat mendorong terjadinya konflik peran ganda.

Menurut Frone, Rusell \& Cooper (dalam Mubassyir dan Herachhwati, 2014) mendefinisikan konflik peran ganda (Work Family Conflict) sebagai bentuk konflik peran dimana tuntutan pekerjaan dan keluarga secara mutual tidak dapat disejajarkan dalam beberapa hal. Tekanan yang dirasakan oleh para wanita yang sudah berkeluarga dirasa lebih tinggi. Karena disamping mereka harus bekerja keras, mereka juga dihadapkan oleh tanggung jawab sebagai ibu rumah tangga. Hal itu akan menyebabkan masalah antara tugas keluarga atau tugas pekerjaan yang ditanggung.

Perawat merupakan salah satu profesi yang didominasi oleh kaum wanita dan sebagai seorang perawat mereka dituntut untuk bekerja dengan beban pekerjaan siaga 24 jam untuk melayani pasien. Saat ini RSUD Sultan Sulaiman memiliki 130 perawat yang terdiri dari 20 perawat pria dan 110 perawat wanita. Instansi 
ini memberlakukan shift untuk jam kerja perawatnya, terutama bagian instalasi gawat darurat dan rawat inap diberlakukan 3 shift karena bagian ini harus selalu siaga melayani pasien selama 24 jam. Shift pertama memulai aktifitasnya mulai pukul 08.00 WIB sampai dengan 16.00 WIB, shift kedua memulai aktifitasnya dari pukul 14.00 WIB sampai dengan 22.00 WIB dan shift ketiga memulai aktifitasnya dari pukul 22.00 WIB sampai pukul 08.00 WIB. Hal ini juga kerap menjadi beban kerja yang dirasakan oleh perawat wanita di RSUD Sultan Sulaiman Sei Rampah.

Menurut beberapa perawat saat wawancara yang dilakukan pada November 2016, sebagai seorang perawat mereka dituntut untuk selalu bertindak profesional dalam pekerjaannya terutama saat menghadapi pasien yang memiliki karakteristik penyakit beragam dengan penanganan yang berbeda pula. Ditambah dengan jam kerja yang terbagi dalam tiga shift membuat mereka terkadang terbengkalai dalam memberikan waktu dengan keluarga. Walaupun demikian mereka dituntut untuk tidak mencampuradukkan pekerjaan dengan masalah yang mereka hadapi di rumah, karena apabila hal tersebut terjadi maka akan ada penurunan kinerja dan akan berdampak bagi kualitas pelayanan yang ada di rumah sakit tersebut.

Selain peran ganda, hal lain yang perlu diperhatikan berkaitan dengan kinerja perawat adalah kecerdasan emosional. Menurut Goleman (dalam Kurnia 2015), kecerdasan emosional adalah kemampuan untuk mengendalikan hal-hal negatif seperti kemarahan dan keragu-raguan atau rasa kurang percaya diri dan kemampuan untuk memusatkan perhatian pada hal-hal positif seperti rasa percaya diri dan keharmonisan dengan orang-orang di sekeliling.

Kecerdasan emosional merupakan faktor yang harus diperhatikan oleh perawat karena mereka yang kerjanya banyak terlibat langsung dengan pasien. Goleman (dalam Mangkunegara 2006) melalui penelitiannya menyatakan bahwa kecerdasan emosi menyumbang $80 \%$ dari faktor penentu kesuksesan seseorang, sedangkan $20 \%$ yang lain ditentukan oleh $I Q$. Begitu pula disimpulkan oleh Joan Beck bahwa IQ sudah berkembang 50\% sebelum usia lima tahun, $80 \%$ berkembangnya sebelum delapan tahun dan hanya berkembang $20 \%$ sampai akhir batas waktu.

Hasil penelitian yang dilakukan oleh Kurnia (2015) menunjukkan bahwa konflik peran ganda dan kecerdasan emosional memiliki pengaruh yang signifikan terhadap kepuasan kerja guru sebesar $70,8 \%$.

Adapun faktor lain yang berpengaruh terhadap kinerja karyawan adalah komitmen organisasi. Komitmen organisasi merupakan kekuatan relatif dari identifikasi individu dan keterlibatannya sebagai kekuatan relative dari identifikasi individu dengan organisasi kerja (Mowday dalam Mubassyir dan Herachhwati 2014). Sumber daya manusia merasakan bahwa organisasi di mana mereka bekerja adalah organisasi yang peduli kepada mereka dan menjadi tempat yang baik untuk bekerja. Karenanya mereka merasa terikat dengan organisasi dan adalah 
tidak layak untuk meninggalkannya (Wibowo, 2015:107). Keadaan ini menunjukkan bahwa sumber daya manusia mempunyai komitmen pada organisasi sehingga dengan demikian sumber daya manusia yang bekerja di organisasi ataupun perusahaan tersebut akan meningkatkan kualitas kerja yang mereka hasilkan. Penelitian yang dilakukan oleh Parwita (2013) Komitmen organisasi berkorelasi positif dengan disiplin kerja. Ini dapat diartikan bahwa apabila dosen berkomitmen pada Universitas Mahasaraswati, maka mereka akan lebih disiplin.

Sebagai seorang perawat, mereka dituntut untuk bertindak profesional. Itu dikarenakan mereka berinteraksi langsung dengan pasien, menjaga serta mengontrol keadaan pasien. Namun di satu sisi mereka merupakan seorang ibu rumah tangga yang dihadapkan dengan keluarga dengan tuntutan yang berbeda pula. Mereka harus menjalankan perannya sebagai seorang istri maupun sebagai seorang ibu bagi anak-anaknya.

Objek penelitian ini adalah seluruh perawat wanita yang berstatus kerja honorer serta yang sudah menikah dan memiliki anak sehingga penelitian ini bermaksud untuk mengetahui beberapa faktor yang mungkin dapat mempengaruhi kinerja wanita yang memiliki peran ganda dalam menjalankan tugas dan tanggung jawabnya sebagai seorang istri maupun sebagai perawat.

\section{KAJIAN PUSTAKA}

Kinerja Karyawan

Menurut Ma'arif dan Kartika (2012:8) menyatakan bahwa Kinerja adalah keluaran (result) yang merupakan real value bagi perusahaan, misalnya berupa jumlah penjualan, jumlah produksi, tingkat kualitas, efesiensi biaya, profit, dan sebagainya. Untuk menghasilkan keluaran (result) tersebut dibutuhkan kompetensi tertentu, seperti kemampuan mengoperasikan mesin, kemampuan mengatur sumber daya dan lain-lain. Oleh karena itu, baikkinerja maupun kompetensi sama-sama penting, tidak ada kinerja jika tidak ada kompetensi.

\section{Konflik Peran Ganda}

Menurut Fahmi (2016:149) konflik adalah sebuah presepsi yang berbeda dalam melihat suatu situasi dan kondisi yang selanjutnya teraplikasi dalam bentuk aksi-aksi sehingga telah menimbulkan pertentangan dengan pihak-pihak tertentu.

Sedangkan peran menurut Luthans (dalam Meidah 2013:10) didefenisikan sebagai suatu posisi yang memiliki harapan yang berkembang dari norma yang dibangun. Menurut Triatna (2015:133) konflik peran terjadi apabila seseorang atau kelompok memiliki lebih dari satu peran. Perbedaan peran akan menjadi konflik manakala membahas atau mengelola suatu hal yang sama atau berkaitan.

\section{Kecerdasan Emosional}

Kata emosi berasal dari bahasa latin yaitu emovere, yang artinya bergerak menjauh. Arti kata ini menyiratkan bahwa kecenderungan bertindak merupakan hal mutlak. Menurut Salovely dan Mayer (dalam Kurnia 2015), kecerdasan emosi adalah kemampuan untuk merasakan emosi, membina dan membangun emosi yang baik, memahami emosi dan pengetahuan 
emosional sehingga dapat meningkatkan perkembangan emosi dan intelektual.

\section{Komitmen Organisasi}

Menurut Greenberg dan Baron (dalam Wibowo, 2014:187) memberikan pengertian komitmen organisasional sebagai suatu tingkatan di mana individu mengidentifikasi dan terlihat dengan organisasinya dan atau tidak ingin meninggalkannya.

Sedangkan menurut Wibowo (2014:188) bahwa komitmen organisasi tersebut pada dasarnya adalah merupkan kesediaan seseorang untuk meningkatkan diri dan menunjukkan loyalitas pada organisasi karena merasakan dirinya terlibat dalam kegiatan organisasi.

\section{METODE PENELITIAN}

Adapun yang menjadi lokasi penelitian ini yaitu di Rumah Sakit Umum Daerah Sultan Sulaiman yang berlokasi di Jl. Negara KM. 58 No.315 Kabupaten Sei Rampah Sumatera Utara 20695, Telp. (0621442100). Populasi dalam penelitian ini adalah tenaga paramedis/perawat wanita Rumah Sakit Umum Daerah Sultan Sulaiman Sei Rampah berjumlah 130 orang. Teknik analisis data yang digunakan dalam penelitian ini adalahanalisis regresi linear berganda.Untuk menguji kebenaran hipotesis pertama digunakan uji $\mathrm{F}$ yaitu untuk menguji keberartian/signifikansi regresi secara keseluruhan.

\section{HASIL DAN PEMBAHASAN}

Berdasarkan data primer yang telah diolah, maka hasil persebaran responden berdasarkan masa kerjadalam penelitian ini bahwa perawat yang menjadi responden dalam penelitian ini terdiri dari 15 orang $(19 \%)$ berada direntang masa kerja $1 \mathrm{~s} / \mathrm{d} 5$ tahun, 57 orang $(73 \%)$ berada direntang masa kerja $6 \mathrm{~s} / \mathrm{d} 10$ tahun, dan 6 orang $(8 \%)$ berada direntang $\geq 11$ tahun. Dalam penelitian 78 orang responden dengan klasifikasi berdasarkan usia, bahwa perawat yang menjadi responden dalam penelitian ini terdiri dari 16 orang $(21 \%)$ berusia $20 \mathrm{~s} / \mathrm{d} 30$ tahun, 48 orang $(61 \%)$ berada direntang usia $31 \mathrm{~s} / \mathrm{d} 40$ tahun, dan 14 orang (18\%) berada direntang usia $\geq 41$ tahun. Dalam penelitian 78 orang responden dengan klasifikasi berdasarkan pendidikan,bahwa perawat yang menjadi responden dalam penelitian ini terdiri dari 0 orang $(0 \%)$ berpendidikan D1, 65 orang $(83 \%)$ berpendidikan D3, 9 orang $(12 \%)$ berpendidikan S1, dan 4 orang $(5 \%)$ berpendidikan Ners.

Hasil dari analisis regresi berganda adalah sebagai berikut : $\mathbf{Y}=$ $10,853+(-0,034) X_{1}+0,571 X_{2}+$ $\mathbf{0 , 4 7 0} \mathbf{X}_{\mathbf{3}}+\mathbf{e}$. Dari hasil SPSS diatas dapat dijelaskan sebagai berikut :

a. Konstan sebesar 10,853 menyatakan bahwa jika tidak ada variabel konflik peran ganda $\left(\mathrm{X}_{1}\right)$, kecerdasan emosional $\left(\mathrm{X}_{2}\right)$ dan komitmen organisasi $\left(\mathrm{X}_{3}\right)$ maka nilai kinerja (Y) adalah 10,853 dengan asumsi faktor lain konstan.

b. Koefisien regresi variabel konflik peran ganda $\left(\mathrm{X}_{1}\right)$ sebesar $-0,034$, artinya jika konflik peran ganda mengalami kenaikan $1 \%$, maka kinerja (Y) akan mengalami penurunan sebesar $-0,034$ 
c. Koefisien regresi variabel kecerdasa emosional $\left(\mathrm{X}_{2}\right)$ sebesar 0.571, artinya jika kecerdasan emosional mengalami kenaikan $1 \%$, maka kinerja (Y) akan mengalami kenaikan 0,571.

d. Koefisien regresi variabel komitmen organisasi $\left(\mathrm{X}_{3}\right)$ sebesar 0.470, artinya jika komitmen organisasi mengalami kenaikan $1 \%$, maka kinerja (Y) akan mengalami kenaikan 0,470

Dari hasil uji $t$ didapatkan hasil sebagai berikut :

1. Nilai t hitung variabel konflik peran ganda $-0,522<$ dari $t_{\text {tabel }}$ yaitu 0,361 dan nilai signifikan 0,603 > 0,05. Hal ini berarti hipotesis ditolak yaitu : Konflik Peran Ganda secara parsial tidak berpengaruh secara positif dan signifikan terhadap kinerja perawat di RSUD Sultan Sulaiman Sei Rampah.

2. Nilai $t$ hitung variabel kecerdasan emosional 4,832 > dari $t_{\text {tabel }}$ yaitu 0,361 dan nilai signifikan $0,000<0,05$. Hal ini berarti hipotesis diterima yaitu: kecerdasan emosional secara parsial berpengaruh positif dan signifikan terhadap kinerja perawat di RSUD Sultan Sulaiman Sei Rampah.

3. Nilai $t$ hitung variabel komitmen organisasi 2,282 > dari $t_{\text {tabel }}$ yaitu 0,361 dan nilai signifikan $0,025<0,05$. Hal ini berarti hipotesis diterima yaitu: komitmen organisasi secara parsial berpengaruh positif dan signifikan terhadap kinerja perawat di RSUD Sultan Sulaiman Sei Rampah.

Dari hasil uji $\mathrm{F}$ didapatkan hasil bahwa nilai $F_{\text {hitung }}=12,052$ dan $\mathrm{F}_{\text {tabel }}=2,73$. Karena $\mathrm{F}_{\text {hitung }}>\mathrm{F}_{\text {tabel }}$ dan tingkat signifikan $<0,05$ yaitu 0,000 $<0,05$ maka H4 diterima sehingga dapat disimpulkan bahwa konflik peran ganda $\left(\mathrm{X}_{1}\right)$, kecerdasan emosional $\left(\mathrm{X}_{2}\right)$ dan komitmen organisasi $\left(\mathrm{X}_{3}\right)$ berpengaruh secara simultan terhadap kinerja (studi pada RSUD Sultan Sulaiman Sei Rampah).

Setelah dilakukan analisis regresi berganda, uji t dan uji f, maka langkah terakhir yang dilakukan adalah melakukan pengujian determinasi R. Hasil dari uji determinasi adalah sebagai berikut :

Dari tabel diatas dapat dilihat besar angka $\mathrm{R}^{2}$ adalah 0,328 , yang artinya variabel $X_{1}, X_{2}$, dan $X_{3}$ menjelaskan pengaruh terhadap variabel Y sebesar 32,8\% $\left(\mathrm{R}^{2}\right.$ x $100 \%$ : $0,328 \times 100 \%=32,8 \%$ ) sedangkan sisanya $67,2 \%\left(100 \%-\mathrm{R}^{2}\right)$ dijelaskan oleh variabel-variabel di luar model penelitian ini.

\section{Pembahasan}

Hasil penelitian ini sejalan dengan penelitian Endah Meidah yang berjudul "Pengaruh Konflik Peran Ganda, Kecerdasan Emosional dan Komitmen Organisasi Terhadap Kinerja Perawat Wanita (Studi Kasus pada RS Islam Jakarta Pondok Kopi). Hal ini dapat terjadi karena perawat yang mengalami konflik peran ganda dapat bersikap profesional dengan tidak mencampur adukkan kepentingan keluarga dengan kepentingan pekerjaan. Ini menunjukkan bahwa perawat wanita yang sudah menikah dan memiliki anak di RSUD Sultan Sulaiman 
memiliki kinerja baik pada organisasi tanpa memandang konflik yang bergejolak didalam keluarga. Bukti bahwa kinerja perawat wanita yang baik dapat dilihat dari rata-rata jawaban kinerja yang berada pada kategori tinggi. Serta hal ini juga diperkuat dengan teori yang dikemukakan oleh Patton (dalam Ifham dan Helmi, 2002) yang mengatakan bahwa kecerdasan emosional merupakan kemampuan untuk menggunakan emosi serta efektif untuk mencapai tujuan, membangun hubungan produktif dan meraih keberhasilan. Serta hal ini juga diperkuat dengan teori yang dikemukakan oleh Luthans (dalam Wibowo, 2014:188) yang mengemukakan bahwa komitmen merupakan suatu sikap yang mencerminkan loyalitas pekerja pada organisasi dan merupakan satu proses yang sedang berjalan melalui mana peserta organisasi menyatakan perhatian mereka terhadap organisasi dan kelanjutan keberhasilan dan kesejahteraannya. Dan menurut Young (dalam Prawita, 2013) ada delapan faktor yang secara positif mempengaruhi komitmen organisasi yaitu adanya promosi, karakteristik pekerjaan, kepemimpinan, pertukaran ekstrinstik, pertukaran intrinstik, imbalan ekstrinstik serta imbalan intrinstik.

\section{SIMPULAN}

Berdasarkan hasil penelitian pada RSUD Sultan Sulaiman Sei Rampah dinyatakan bahwa variabel konflik peran ganda tidak berpengaruh secara signifikan terhadap kinerja. Kecerdasan emosional berpengaruh secara secara signifikan terhadap kinerja di RSUD Sultan Sulaiman. Komitmen organisasi berpengaruh secara secara signifikan terhadap kinerja di RSUD Sultan Sulaiman. Variabel konflik peran ganda, kecerdasan emosional dan komitmen organisasi secara bersama-sama mempengaruhi kinerja pada RSUD Sultan Sulaiman.

\section{DAFTAR PUSTAKA}

Fahmi, Irfan. 2016. Perilaku Organisasi: Teori, Aplikasi dan Kasus. Bandung: Alfabeta

Ifham, Ahmad dan Helmi, Avin F. 2002. Hubungan Kecerdasan Emosi Dengan Kewirausahaan Pada Mahasiswa. Jurnal Psikologi, Vol.2 No.2 Pp 89111

Jacinta R.F. "Wanita

Bekerja".http://www.e-

psikologi.com, 28 Mei 2002.

Kurnia, Fajar. 2015. Pengaruh Konflik Peran Ganda dan Kecerdasan Emosional

Terhadap Kepuasan Kerja Guru Sekolah Luar Biasa Negeri Pembina Provinsi Riau. Jom Fekon, Vol. 2 No.1 Februari 2015

Ma'arif, M Syamsul dan Kartika, Lindawati. 2012. Manajemen Sumber Daya

$\begin{array}{lr}\text { Manusia: } & \text { Implementasi } \\ \text { Menuju } & \text { Organisasi } \\ \text { Berkelanjutan. } & \text { Bogor: IPB } \\ \text { Pers } & \end{array}$

Mangkumanegara, 2006.Evaluasi Kinerja SDM. Bandung: PT Refika Adita.

Meidah, Endah. 2013. Pengaruh Konflik Peran Ganda, Kecerdasan Emosional dan 
JURNAL PLANS

Penelitian Ilmu Manajemen \& Bisnis

ISSN: 1978-7057

E-ISSN: 2527-306X

Komitmen Organisasi

Husada Surabaya. Jurnal

Terhadap Kinerja Perawat

Manajemen Teori dan

Wanita (Study Kasus Pada RS

Terapan, Vol.7 No.3

Islam Jakarta Pondok

Kopi).Skripsi. Jakarta.

Universitas Islam Negeri

Syarif Hidayatullah, Fakultas

Ekonomi dan Bisnis

Mubassyir, Ahmad Hilmy dan

Herachwati, Nuri. 2014.

Pengaruh Work-Family

Conflict Terhadap Kinerja

Perawat Wanita Dengan

Variabel Intervening

Komitmen Oeganisasional di

RSUD Bhakti Dharma

Parwita, Gde Bayu Surya. 2013.

Pengaruh Kepuasan Kerja Terhadap

Komitmen

Organisasi dan Disiplin Kerja (Studi Pada Dosen Yayasan Universitas Mahasaraswati Denpasar). Tesis. Magister Pasca Sarjana, Universitas Udayana

Wibowo. 2015. Perilaku dalam

Organisasi. Depok: PT Rajagrafindo

Persad 